\title{
Intellectual Capital, Technological Intensity and Firm Performance: The Case of Emerging Countries
}

\author{
Mehtap Öner*iD, Aslı Aybars**iD, Murat Çinko***iD, Emin Avcı
}

\begin{abstract}
While neglecting the importance of technological intensity, most of the prior studies documented the positive contribution of intellectual capital (IC) to corporate financial performance. This study aims at analyzing the relation between IC and corporate financial performance addressing the technological intensity in different sectors from 17 emerging countries. The impact of IC, which is measured by Value Added Intellectual Coefficient (VAIC) and its components; Capital Employed Efficiency (CEE), Human Capital Efficiency (HCE), and Structural Capital Efficiency (SCE), on corporate financial performance will be evaluated using panel data analysis for the period between 2009-2019. Accordingly, IC and its components are found to be significant drivers of financial performance being higher for sectors that are more technology intensive. Moreover, human and physical capital are the main components, which boost finance performance for all groups irrespective of technological intensity in the emerging market context.
\end{abstract}

Keywords: emerging markets; Value Added Intellectual Coefficient; technological intensity; financial performance; panel data.

JEL classification: C23; L25; O34.

\section{INTRODUCTION}

Intellectual Capital (IC) is a concept of utter importance in the companies' value creation and performance improvement processes as it takes into account knowledge-based assets that have a potential of leading the company to competitive advantage in the long-term. The significance of the nexus between IC and financial performance is increasing because companies should also rely on intangible assets besides tangibles to create value and improve their performance. It is important to note that not all tangible and intangible assets qualify for being strategic assets, which are cornerstones of sustainable financial performance and tools

\footnotetext{
*Marmara University, Turkey; e-mail: mehtap.oner@marmara.edu.tr (corresponding author).

*** Marmara University, Turkey; e-mail: asli.aybars@marmara.edu.tr.

**** Marmara University, Turkey; e-mail: mcinko@marmara.edu.tr.

§armara University, Turkey; e-mail: eavci@marmara.edu.tr.
} 
for differentiation from the competitors. Whereas physical assets are easier to accumulate, knowledge-based assets are specific, not easily substitutable and hard to imitate, as such assets require high level of technology. For this reason, technology intensive companies may have an advantage on accumulation of knowledge-based assets. Such advantages may lead value creation, increase the significance of IC and also financial performance.

Numerous researchers have analyzed the relation between IC and financial performance; several articles have already been published in the related literature. However, the technology level or intensity of the technology utilized in each sector is dramatically different from each other. Hence, diversity in technological intensity will result in differences in IC components (Buenechea-Elberdin, 2017) because technological intensity differences probably will cause differences in knowledge accumulations among companies (Buenechea-Elberdin, Saenz, \& Kianto, 2018). Thus, it is logical to expect that such technological diversity may affect the relation between IC and financial performance.

Utilizing a final dataset of 504 non-financial firms across 17 countries, which are selected from Morgan Stanley Capital International (MSCI) Emerging Market Index, the influence of intellectual capital and its components, which is proxied by Value Added Intellectual Coefficient (VAIC), on corporate financial performance is investigated for the period between 2009 and 2019. Following Palazzi, Sgro, Ciambotti, and Bontis (2020), the whole sample is categorized into high, medium-high, medium-low, and low technology industries by using Thomsen Reuters Business Classification according to technological concentration based on technological intensity.

The rest of the study is structured as follows: Section 2 provides literature review on the nexus between IC and financial performance. Methodology is displayed in Section 3 together with the dataset, variables utilized, and research design. The results of the models are provided in detail in Section 4. The last section is devoted to discussions and conclusion.

\section{LITERATURE REVIEW}

As stated by Stewart (1997), "what gets measured gets managed". The significant role of knowledge for companies to prosper and grow is one of the driving factors of the attempt to measure the knowledge-based assets, specifically IC. The concept of IC has been first published by John Kenneth Galbraith in 1969. He defines IC as an ideological process rather than a pure intangible asset (Bontis, 1998, p. 67). Later, numerous definitions focusing on different perspectives of the concept have been put forth by different academicians and practitioners. One of the most commonly referred to definitions of IC is that of Stewart (1997), who defines it as "the intellectual material - knowledge, information, intellectual property, experience - that can be put to use to create wealth". Concurrently, Edvinsson (1997) states IC to be the interaction between human and structural capital. As further stated in the work of Edvinsson and Malone (1997, p. 44), IC is explained as "the possession of knowledge, applied experience, organizational technology, customer relationships and professional skills that provide the firm with a competitive edge in the market". Moreover, it is emphasized that the difference between the firms' book and market values can be attributed to accumulation of IC. On the other hand, the definition of IC is restricted to the sum of intangible assets by Bontis, Keow, and Richardson (2000). Similarly, Roos and Roos (1997), who perceive IC as a crucial tool to attain sustainable competitive advantage for companies, describe the concept to consist of the company's hidden assets not thoroughly seen on the balance sheet. Even 
though there are various definitions focusing on different aspects of IC, a common basis in terms of definitions can be intuitively noticed as the concept being composed of non-monetary and non-physical/intangible resources that generate value for the firms through knowledge, processes, relationships, and databases within the organization.

As far as the literature review is concerned, IC is assumed to comprise various components. Whereas some of the researchers utilize a two-element categorization scheme focusing on human capital (HC) and structural capital (SC) (Edvinsson \& Malone, 1997; Hall, 1992; OECD, 1999; Petty \& Guthrie, 2000; Pulic, 2004), others have focused on a threeelement version by adding the relational capital (RC) to the concept (Bontis, 2001; Sveiby, 1997). In general, HC is regarded to encompass the knowledge, innovativeness, skills, competence, motivation, loyalty, commitment, and wisdom of the employees within the organization (Bontis et al., 2000; Sardo \& Serrasqueiro, 2017; Xu \& Wang, 2018). While Roos and Roos (1997, p. 13) classify HC into elements named as knowledge, skill, motivation, and task capital; Bontis (1998) expresses the concept as the firm's collective capability that is composed of the knowledge and personality attributes of its employees. Since all these features are possessed individually, the departure of the people may cause corporate memory loss, which is a potential threat to the organization. Crane and Bontis (2014) further stress the importance of this capital in achieving sustainable organizational advantage. A common point in all these expressions is the uniqueness of this form of capital, which is essential for attaining competitive privilege and creating value for organizational success. As also stressed by Johnson (1999, p. 565) majority of a firm's market value is obtained through human intellect and innovation that represent HC. Thus, this element of IC adds to the innovative capacity of the knowledge-based firms.

Structural capital, the other component that is widely accepted to be part of IC, is referred to as the combination of patents, copyrights, trademarks, databases, systems, distribution networks, supply chains, procedures, capabilities, and culture in an organization (Bontis et al., 2000; Petty \& Guthrie, 2000; Sardo \& Serrasqueiro, 2017). Roos, Roos, Edvinsson, and Dragonetti (1997, p. 42) express SC as "what remains in the company when employees go home for the night". Similarly, Bontis et al. (2000) sum up all the above items as non-human storehouses of knowledge within the definition of SC. Having a steady and sound SC motivate people within the organization to constantly learn with trial and error (Bontis, 1998, p. 66). This culture generates an environment that promotes success while making people not afraid of any potential mistakes as they are supposed to constantly learn from their failures. Thus, $\mathrm{SC}$ is a critical element of intellectual capital that helps to improve and support HC.

Apart from other components of IC, customer or relational capital is more externally oriented. It is expressed as intellectual assets accumulated through external relationships of the firms with all possible interested groups such as suppliers, marketing channels, customers, competitors, government or any trading partners (Bontis et al., 2000). Petty and Guthrie (2000, p. 166) further state that this component encompasses brand and company names, customer loyalty, business cooperation, licensing and franchising agreements. This form of capital helps to create value making the firm have favorable bonds with the business community members through improvement of human and structural capital (Johnson, 1999, p. 567). It has to be noted that bringing internal intellectual resources together with the IC generated through external relationships helps organizations create value.

Numerous researches have been conducted in different countries and regions with firms from various industries to reveal the influence of IC on firm performance. The study 
performed by Firer and Williams (2003) evaluates the influence of physical capital, human capital, and structural capital efficiency on corporate performance, productivity, and market value with a dataset of 75 South African listed firms. The outputs of the analysis are mixed and limited in that corporate profitability is found to be affected mostly by physical capital while moderately by the structural capital. A concurrent study with evidence on Japanese banks performed by Mavridis (2004) shows performance differences among banks in that banks with best performances are those that use human capital more and physical capital less. Similar findings are supported by Goh (2005) for Malaysian banking sector with human capital investments demonstrating greater importance in generating higher return in comparison to physical and structural capital investments.

Another study, which investigates the association between IC components and both financial performance and market value of companies traded on Athens Stock Exchange, failed to document significant links except for the one between human capital efficiency and profitability (Maditinos, Chatzoudes, Tsairidis, \& Theriou, 2011). UK based findings by Zeghal and Maaloul (2010) reveal the significant influence of IC on financial performance for all sectors analyzed but the positive link of IC with the stock market performance is evident only for the high-tech industry. Rahman (2012) also reveals the positive link between IC and financial performance with highest contribution being from human capital for UK listed firms, whereas no such link has been found with stock market performance.

The positive link between IC and profitability is supported by Sumedrea (2013) utilizing a dataset on non-financial companies listed on Bucharest Stock Exchange. Nadeem, Gan, and Nyugen (2016) perform a research on London Stock Exchange between the years 2005 and 2014 with dynamic panel data analysis and also document the positive influence of IC on particularly ROA and weakly on ROE. While structural and physical capital are found to be significant contributors to financial performance, human capital is not. They further investigated this relationship in BRICS economies and came up with similar results in that all individual components of intellectual capital are found to positively contribute to financial performance (Nadeem, Gan, \& Nyugen, 2017). Similarly, the study conducted with an Australian dataset reveals the same findings as that in BRICS economies further stressing the importance of IC on firm performance (Nadeem, Gan, \& Nyugen, 2018). A more comprehensive study with a dataset of ten emerging and developed markets also supports the same findings using both VAIC and adjusted VAIC methodologies (Nadeem, Dumay, \& Massaro, 2019). The positive impact of IC and its components; namely, physical capital, human capital, and relational capital on financial performance has also been found in the Korean manufacturing industry. Among the components, the most influential factor is documented to be relational capital (Xu \& Wang, 2018).

Regarding the findings of Sardo and Serrasqueiro (2017) with a dataset of 14 Western European non-financial listed firms, the positive link between IC and financial performance has further been revealed with the influence of human capital efficiency and capital employed efficiency being the most. The positive evidence regarding the impact of IC on the financial performance of small and medium-sized Portuguese hotels is also revealed by Sardo, Serrasqueiro, and Alves (2018). Among the components, human and relational capital are found to be the main contributors to financial performance. Ginesti, Caldarelli, and Zampella (2018) further prove the positive influence of IC on various measures of financial performance for Italian listed firms. Additionally, it has been documented by Jordao and Almeida (2017) 
that the more intangible-intensive Brazilian listed companies are, the better the long-term financial performance they demonstrate.

Dzenopoljac, Yaacoub, Elkanj, and Bontis (2017) utilize data belonging to ten countries from the Arab region to evaluate the impact of IC components on various measures of performance. The results of the analyses are different based on the selected measures in that whereas physical capital is found to significantly influence ROE; structural and physical capital are found to significantly affect ROA. The comparative study focusing on the link between accounting and market-based measures of financial performance and IC reveals mixed results for Saudi Arabia and Bahrain. Even though IC is found to exert a positive influence on the accounting measure, no significant relationship has been found for the market-based measure in Saudi Arabia. Contrarily, only structural and human capital efficiency are found to be positively linked to the accounting and market-based measures, respectively (Hamdan, 2018).

Similar findings showing the contribution of IC on corporate performance have been found in the Asian region as well. Tan, Plowman, and Hancock (2007) prove this association for the listed companies in Singapore. This positive relationship is also seen in the results of Phusavat, Comepa, Sitko-Lutek, and Ooi (2011) for Thailand with the selected profitability measures. A cross-country study on technology firms based on selected ASEAN countries utilizes relational capital efficiency as an additional variable to the traditional VAIC model. The evidence shows that capital employed and human capital efficiencies are the more influential contributors to performance when compared with structural and relational capital efficiencies. Furthermore, the positive link between IC and financial performance is revealed with no significant difference across the countries (Nimtrakoon, 2015). An analysis conducted on Indian listed companies demonstrate that IC and capital employed efficiency are significant drivers of financial performance while human and structural capital are not (Smriti \& Das, 2018).

A research based on firms listed in Borsa İstanbul (BIST) shows the significant contribution of IC on firm financial performance with all IC components except structural capital efficiency (Akpına \& Akpınar, 2016). Another study focusing on this relationship specifically for initial public offerings in BIST also supports the positive influence of IC on firm profitability (Gülcemal \& Çıtak, 2017). Parallel findings are further found in Turkish banking sector with capital employed and human capital efficiencies positively affecting financial performance with the impact of capital employed efficiency being more Özkan, Cakan, and Kayacan (2017). Affirmative results for the Turkish banking sector stating that IC enhances profitability have also been put forth in literature (Kayacan \& Özkan, 2015; Sakur, 2017). Another study on Turkish financial sector documented that the relations between IC and financial performance depends on the performance criteria, where IC contribution can be observed more on ROA and ROE (Avc1 \& Nassar, 2017). Further evidence from Thai listed banks shows capital employed efficiency to be the main contributor to financial performance; whereas, human capital efficiency is found to reduce profitability in the current period. However, the positive influence of this efficiency is detected for future periods (Tran \& Vo, 2018). Recent evidence focusing on Islamic banks in Gulf Cooperation Council (GCC) countries reveal IC to be positively correlated with financial performance with human capital efficiency being a more important contributor when compared to capital employed and structural capital efficiencies (Ousama, Hammami, \& Abdulkarim, 2020).

A recent study on Indian listed companies provides evidence that IC is a driver of financial performance with capital employed efficiency being the most influential component followed by human capital efficiency (Weqar, Sofi, \& Haque, 2020). Similarly, further Indian 
evidence shows IC as a driver of profitability and value for infrastructure firms, while capital employed efficiency is found to positively affect profitability for infrastructure and real estate firms (Singla, 2020). Recent findings on Spanish SMEs show that both IC and its components add to firm financial performance (Ramirez, Dieguez-Soto, \& Manzaneque, 2021). Contradictory findings for Taiwanese electronics industry are documented by Ting, Ren, Chen, and Kweh (2020) with IC having a negative influence on firm performance. At component level; while human and structural capital efficiencies are found to be positively related with performance, capital employed efficiency is found to exert such a large negative influence on performance that the other components' positive influences are offset.

Referring the importance of R\&D investments on accumulation of knowledge-based assets, another strand of the research has been concentrated on the relationship between IC and financial performance under the light of technological intensity. Among those, Sardo and Serrasqueiro (2018) demonstrate the positive association between IC and financial performance of high, medium, and low-tech European firms. By classifying the Chinese SMEs as high-tech and low-tech companies, $\mathrm{Xu}$ and $\mathrm{Li}$ (2019) examine the effect of IC and its components on earnings, profitability and efficiency. Their findings reveal a positive effect of IC on performance for both company classes, while IC has a greater impact on earnings and efficiency in low-tech companies. In the case of earnings, CEE and SCE has greater impact on low-tech companies and HCE has a greater impact on high-tech companies. The findings regarding to effect of IC on profitability present diverse results for each class and profitability measure.

As the literature review demonstrates, most of the prior studies support the positive contribution of IC or any of its components to corporate financial performance. Accordingly, few studies fail to document this positive relationship. The study performed by Chan (2009) provides no supportive results for the nexus between IC and financial performance indicators for the listed firms in Hong Kong. Further evidence based on Italian listed companies shows no significant link between IC and the selected indicators of firm performance (Celenza \& Rossi, 2014). The controversial results can be adhered to country and industry specific factors together with the periods analyzed. Additionally, Nadeem et al. (2016) emphasize that literature majorly focuses on the unidirectional link between IC and performance without focusing on the potential influence of prior year performance on IC.

\section{DATA AND METHODOLOGY}

The hypothesis development of this study rests majorly upon the resource-based view of the firm, which states that strategic assets encompassing both tangible and intangible assets are the main contributors to competitive advantage and enhanced performance (Wernerfelt, 1984). According to Barney (1991), for a resource to exert sustained competitive advantage it must be valuable, rare, imperfectly imitable, and nonsubstitutable. IC has been regarded in literature as a strategic resource that creates value enabling the firm to attain competitive advantage and; thus, improve the performance of the firm (Clarke, Seng, \& Whiting, 2011; Stewart, 1997). The positive association between IC and performance has been supported by numerous empirical studies (Dzenopoljac et al., 2017; Nadeem et al., 2017; Nimtrakoon, 2015; Sumedrea, 2013; Tan et al., 2007; Weqar et al., 2020). Based on the above stated arguments, IC has a crucial role in enhancing firm financial performance in line with resourcebased view. Accordingly, the first hypothesis is generated as follows:

$\mathrm{H}_{1}$ : IC will be positively related with firm financial performance. 
Following the prior studies in literature and on the grounds that IC components have potential to influence firm performance at different levels, further analyses are conducted to observe the individual impact of Capital Employed Efficiency (CEE), Human Capital Efficiency (HCE), and Structural Capital Efficiency (SCE) (Dzenopoljac et al., 2017; Firer \& Williams, 2003; Maditinos et al., 2011; Sardo \& Serrasqueiro, 2017). According to Pulic (1998), inefficient use of physical capital, which is captured by CEE, deteriorates performance. Furthermore, effective utilization of human resources will add to performance, which is emphasized by Bontis (1998) in that HCE as a source of innovation in a knowledge-based economy improves performance. Lastly, SCE, that comprises the non-human storehouses of knowledge, helps IC to reach its fullest potential for achieving sustainable performance. Accordingly, the below hypotheses are generated:

$\mathrm{H}_{1 \mathrm{a}}$ : CEE will be positively related with firm financial performance.

$\mathrm{H}_{1 \mathrm{~b}}$ : $\mathrm{HCE}$ will be positively related with firm financial performance.

$\mathrm{H}_{1 \mathrm{c}}$ : SCE will be positively related with firm financial performance.

\subsection{Methodology}

Numerous methodologies have been generated in literature to quantify and measure IC and its components. This study attempts to probe the link between IC and financial performance on a dataset of selected emerging countries covering the period between the years 2009 and 2019, inclusive. Value added intellectual coefficient (VAIC), developed by Pulic (1998) and Pulic (2004), is utilized as an indicator of IC. Since this methodology focuses on human, structural, and physical dimensions that incorporates every resource into the value creation process, it has widely been used in prior academic work (Chan, 2009; Smriti \& Das, 2018; Yalaman \& Coşkun, 2007). Accordingly, panel data analysis is employed to reveal the relationship under question. Depending on the above stated aim of the study, the impact of IC and its components; namely, CEE, HCE, and SCE, on firm financial performance will be evaluated using panel data analysis. This methodology enables data variability, enhanced informativeness, and higher degrees of freedom by combining time series and cross-sectional observations. Thus, it is considered to be superior to those models that focus only on one of these dimensions. While time series and cross-sectional analysis can generate biased results in case of heterogeneity, panel data can control for this heterogeneity (Baltagi, 2001). Furthermore, it helps to reduce the problem of multi-collinearity (Wooldridge, 2002).

\subsection{Data Set}

To evaluate the influence of IC and its components on financial performance taking technological intensity into account, this study focuses on firms from emerging countries based on the Morgan Stanley Capital International (MSCI) Emerging Market classification. This classification covers countries from regions, namely; Asia, Americas, and Europe, Middle East \& Africa. After eliminating companies with insufficient information for all variables selected to enable appropriate technology intensive group classifications in line with Palazzi et al. (2020), the final dataset is constructed as a balanced sample. The final dataset comprise 504 non-financial firms listed in 17 countries as can be seen in Table no. 1. Because the data used in this study covers public firms from various emerging countries, Thomsen Reuters database is used to enable data consistency. The 11-year period between 2009 and 2019 is utilized to critically analyze the accumulation of IC and its potential influence on financial performance taking technological intensity of the firms into account. 
Table no. 1 - Number of firms in each group with respective countries

\begin{tabular}{lccccc}
\hline Country & Group 1 & Group 2 & Group 3 & Group 4 & Total \\
\hline Argentina & 1 & & 1 & 2 & 4 \\
Brazil & & 1 & & 2 & 3 \\
Chile & & & 2 & 1 & 3 \\
Colombia & & & 1 & 3 & 4 \\
Greece & 3 & 7 & 13 & 27 & 1 \\
Indonesia & 6 & 8 & 17 & 34 & 65 \\
Malaysia & & & 3 & 1 & 4 \\
Mexico & & 1 & 3 & 5 & 9 \\
Peru & 1 & 3 & 3 & 2 & 6 \\
Philippines & & 2 & & 4 & 11 \\
Poland & 1 & 3 & 3 & 8 & 2 \\
Russia & 5 & 5 & 4 & 5 & 15 \\
South Africa & 55 & 64 & 51 & 35 & 205 \\
South Korea & 1 & 11 & 18 & 23 & 53 \\
Taiwan & 3 & 12 & 22 & 13 & 50 \\
Thailand & & & 18 & $\mathbf{1 6 5}$ & $\mathbf{5 0 4}$ \\
Turkey & $\mathbf{7 6}$ & $\mathbf{1 1 7}$ & $\mathbf{1 4 6}$ & & \\
\hline Total number of firms & & & &
\end{tabular}

Palazzi et al. (2020) based their study on OECD Classification of Manufacturing Industries by Technological Intensity, which is a Nace Rev. 2 Classification of manufacturing industries by technological intensity. This study depends on equivalent Thomsen Reuters Business Classification based on R\&D Intensity; however, by following Palazzi et al. (2020), such classification has been modified to present the technological intensity. The industrial classification used in this study is given in Table no. 2 .

Table no. 2 - Industrial classification by technological intensity based on Thomsen Reuters Database

\begin{tabular}{|c|c|c|c|c|}
\hline Group & $\begin{array}{c}\text { Technological } \\
\text { Intensity }\end{array}$ & $\begin{array}{c}\text { Thomsen } \\
\text { Reuters Code }\end{array}$ & Industry Name & $\begin{array}{l}\text { Number of } \\
\text { Companies }\end{array}$ \\
\hline 1 & $\begin{array}{l}\text { High } \\
\text { Technology }\end{array}$ & $\begin{array}{l}52101010 \\
52102040 \\
56101020 \\
56201040 \\
57102010 \\
57104010 \\
57106030 \\
\end{array}$ & $\begin{array}{l}\text { Aerospace \& Defense } \\
\text { Heavy Electrical Equipment } \\
\text { Medical Equipment, Supplies \& Distribution } \\
\text { Pharmaceuticals } \\
\text { Communications \& Networking } \\
\text { Electronic Equipment \& Parts } \\
\text { Household Electronics }\end{array}$ & 76 \\
\hline 2 & $\begin{array}{l}\text { Medium-high } \\
\text { Technology }\end{array}$ & $\begin{array}{l}51101020 \\
52102010 \\
52102020 \\
52102030 \\
53101010 \\
53101020 \\
\end{array}$ & $\begin{array}{l}\text { Agricultural Chemicals } \\
\text { Industrial Machinery \& Equipment } \\
\text { Heavy Machinery \& Vehicles } \\
\text { Electrical Components \& Equipment } \\
\text { Auto \& Truck Manufacturers } \\
\text { Auto, Truck \& Motorcycle Parts } \\
\end{array}$ & 117 \\
\hline 3 & $\begin{array}{l}\text { Medium-low } \\
\text { Technology }\end{array}$ & $\begin{array}{l}50102030 \\
51101010 \\
51201020 \\
51202010 \\
53101030 \\
53203020 \\
53204030\end{array}$ & $\begin{array}{l}\text { Oil \& Gas Refining and Marketing } \\
\text { Commodity Chemicals } \\
\text { Iron \& Steel } \\
\text { Construction Materials } \\
\text { Tires \& Rubber Products } \\
\text { Construction Supplies \& Fixtures } \\
\text { Appliances, Tools \& Housewares }\end{array}$ & 146 \\
\hline
\end{tabular}




\begin{tabular}{|c|c|c|c|c|}
\hline Group & $\begin{array}{c}\text { Technological } \\
\text { Intensity }\end{array}$ & $\begin{array}{c}\text { Thomsen } \\
\text { Reuters Code }\end{array}$ & Industry Name & $\begin{array}{l}\text { Number of } \\
\text { Companies }\end{array}$ \\
\hline 4 & Low & $\begin{array}{l}51301010 \\
51301020 \\
51302010 \\
51302020 \\
52203020 \\
53202010 \\
53202020 \\
53204040 \\
53403040 \\
54101010 \\
54101030 \\
54102010 \\
54102020\end{array}$ & $\begin{array}{l}\text { Forest \& Wood Products } \\
\text { Paper Products } \\
\text { Non-Paper Containers \& Packaging } \\
\text { Paper Packaging } \\
\text { Commercial Printing Services } \\
\text { Textiles \& Leather Goods } \\
\text { Apparel \& Accessories } \\
\text { Home Furnishings } \\
\text { Apparel \& Accessories Retailers } \\
\text { Brewers } \\
\text { Non-Alcoholic Beverages } \\
\text { Fishing \& Farming } \\
\text { Food Processing }\end{array}$ & 165 \\
\hline
\end{tabular}

\subsection{The Variables Utilized}

As this study attempts to evaluate the nexus between IC and firm financial performance, the dependent variables are selected to be traditional measures of performance; namely, ROA and ROE. These measures are calculated as net income to total assets and net income to total equity of the firm, respectively (Chan, 2009; Firer \& Williams, 2003; Maditinos et al., 2011; Özkan et al., 2017; Sardo \& Serrasqueiro, 2018; Sumedrea, 2013; Weqar et al., 2020; Zeghal \& Maaloul, 2010).

This study utilizes VAIC, which has been generated by Pulic (1998) and Pulic (2004), and its components as explanatory variables in different models to proxy for IC. One of the reasons why VAIC model has been selected is its being derived from audited financial statements; thus, resulting standardization and comparativeness that achieves consistency across the whole dataset. As also stated by Firer and Williams (2003), this measure better enables international comparison in large datasets across different industries. Furthermore; the ease of calculation, objectivity and verifiability of the model add to its frequent use in this array of literature (Chan, 2009; Nadeem et al., 2017; Smriti \& Das, 2018; Yalaman \& Coşkun, 2007). Pulic (2004) replaces traditional performance measures with those based on value-added since the formers display no information about the value creation for the stakeholders.

Even though the model is frequently used in literature, it is still subject to contradictory views. The model is criticized due to its monocriterial feature in that a multicriterial feature combining more than one proxy measure for performance measuring different perspectives would provide to be complementary other than its rivals (Iazzolino \& Laise, 2013). Further criticisms have been put forth by Stahle, Stahle, and Aho (2011) on the grounds that what VAIC actually measures is related with the labor and capital investments other than the exact IC of the company, which results in the misuse of IC concepts. Contrary to these shortcomings and oppositions, an increasing number of studies has still been using VAIC method to quantify IC as demonstrated in the literature review section. In his work, Chan (2009) summarizes the reasonings of VAIC utilization as the following. Relevant data that is objective, informative and quantifiable is provided by this methodology since it rests upon publicly available financial data. In line with the IC definitions in literature, human capital is regarded to be one of the most significant components of VAIC. Furthermore, as it produces a standardized measure, it enables comparison across divisions, companies, industries, and countries. Its ease 
of calculation and straightforward methodology also makes this measure user friendly for all potential interested parties.

VAIC utilizes value added as a measure of business success generated by overall resources of the firm; namely, human, structural, and physical (Pulic, 1998, 2004) and is calculated as the difference between output and input:

where,

$$
\mathrm{VA}_{\mathrm{it}}=\mathrm{OUT}_{\mathrm{it}}-\mathrm{IN}_{\mathrm{it}}
$$

$\mathrm{VA}_{\mathrm{it}}=$ Value added of firm i for year $\mathrm{t}$

$\mathrm{OUT}_{\text {it }}=$ Total revenue of firm $\mathrm{i}$ for year $\mathrm{t}$

$\mathrm{IN}_{\mathrm{it}}=$ cost of bought-in materials, components and services of firm i for year $\mathrm{t}$.

However, VA can be calculated as below in line with literature (Bontis, Janosevic, \& Dzenopoljac, 2015; Nadeem et al., 2017; Pulic, 2004; Smriti \& Das, 2018; Yao, Haris, Tariq, Javaid, \& Khan, 2019):

where,

$$
\mathrm{VA}_{\mathrm{it}}=\mathrm{OPit}+\mathrm{HCit}+\mathrm{Dit}+\mathrm{A}_{\mathrm{it}}
$$

$\mathrm{OP}_{\mathrm{it}}=$ operating profit for firm $\mathrm{i}$ at year $\mathrm{t}$

$\mathrm{HC}_{\mathrm{it}}=$ employee cost (salaries, wages, and other benefits) for firm $\mathrm{i}$ at year $\mathrm{t}$

$D_{i t}=$ depreciation expense for firm $\mathrm{i}$ at year $\mathrm{t}$

$\mathrm{A}_{\mathrm{it}}=$ amortization expense for firm $\mathrm{i}$ at year $\mathrm{t}$.

The next step to be followed after the computation of value added is to calculate and add up individual efficiency indicators that make up VAIC. According to Pulic (2004), VAIC comprises Capital Employed Efficiency Coefficient (CEE), Human Capital Efficiency Coefficient (HCE), and Structural Capital Efficiency Coefficient (SCE) as three key components. Thus:

$$
\mathrm{VAICi}_{\mathrm{t}}=\mathrm{CEE}_{\mathrm{it}}+\mathrm{HCE}_{\mathrm{it}}+\mathrm{SCE}_{\mathrm{it}}
$$

It has to be further stated that, adding up the partial efficiencies of human and structural capital results in intellectual capital efficiency (ICE) as below:

$$
\mathrm{ICE}_{\mathrm{it}}=\mathrm{HCE}_{\mathrm{it}}+\mathrm{SCE}_{\mathrm{it}}
$$

The individual components are calculated as follows:

$$
\begin{aligned}
\mathrm{CEE}_{\mathrm{it}} & =\mathrm{VA}_{\mathrm{it}} / \mathrm{CE}_{\mathrm{it}} \\
\mathrm{HCE}_{\mathrm{it}} & =\mathrm{VA}_{\mathrm{it}} / \mathrm{HC}_{\mathrm{it}} \\
\mathrm{SCE}_{\mathrm{it}} & =\mathrm{SC}_{\mathrm{it}} / \mathrm{VA}_{\mathrm{it}}
\end{aligned}
$$

where $\mathrm{CE}_{\mathrm{it}}$ stands for capital employed computed as book value of assets; $\mathrm{HC}_{\mathrm{it}}$ proxies human capital as an indicator of employee expenses, including salaries, wages, and all other expenses incurred on employees and lastly $\mathrm{SC}_{\mathrm{it}}$ represents structural capital that is computed as below:

$$
\mathrm{SC}_{\mathrm{it}}=\mathrm{VA}_{\mathrm{it}}-\mathrm{HC}_{\mathrm{it}}
$$


Due to the fact that firm financial performance can be affected by variables other than IC, firm size and leverage are also incorporated into the models as control variables. Consistent with the prior studies, while firm size is measured as natural logarithm of total assets (Chan, 2009; Nimtrakoon, 2015; Sardo et al., 2018; Ting et al., 2020; Yao et al., 2019; Zeghal \& Maaloul, 2010); leverage is measured as total debt to total assets (Chan, 2009; Dzenopoljac et al., 2017; Firer \& Williams, 2003; Ramirez et al., 2021; Xu \& Li, 2020; Yao et al., 2019).

All the variables utilized together with their abbreviations and definitions are provided in Table no. 3 below.

Table no. 3 - The variables used in the study and their abbreviations

\begin{tabular}{lcl}
\hline Variable & Abbreviation & Definition \\
\hline Dependent Variables & & \\
\hline Return on Assets & ROA $_{i t}$ & Net income/Total assets for firm i at year t \\
Return on Equity & ROE $_{i t}$ & Net income/Total equity for firm i at year t \\
\hline Explanatory Variables & & \\
\hline Value Added Intellectual & VAIC & $V A I C_{i t}=C E E_{i t}+H C E_{i t}+S C E_{i t}$ \\
Coefficient & $C E E_{i t}$ & $V A_{i t} / C E_{i t}$ \\
Capital Employed Efficiency & $H C E_{i t}$ & $V A i t / H C_{i}$ \\
Human Capital Efficiency & $S C E_{i t}$ & $S C i t / V A_{i t}$ \\
Structural Capital Efficiency & & \\
\hline Control Variables & $S I Z E_{i t}$ & Natural logarithm of total assets for firm $i$ at year $t$ \\
\hline Size & $L E V_{i t}$ & Total debt/Total assets for firm $i$ at year $t$ \\
Leverage & & \\
\hline Variables for VAIC computation & $V A_{i t}$ & $O P_{i t}+H C_{i t}+D_{i t}+A_{i t}$ \\
\hline Value Added & $O P_{i t}$ & Operating profit for firm i at year t \\
Operating Profit & $H C_{i t}$ & Employee cost (salaries, wages, and others) for firm \\
Employee Cost & i at year t \\
Depreciation Expense & $D_{i t}$ & Depreciation expense for firm $i$ at year $t$ \\
Amortization Expense & $A C E_{i t}$ & Amortization expense for firm $i$ at year $t$ \\
Intellectual Capital Efficiency & $H C E_{i t}+S C E_{i t}$ \\
Structural Capital & $S C_{i t}$ & $V A_{i t}-H C_{i t}$ \\
\hline
\end{tabular}

\subsection{Research Design}

To test the hypothesis generated and comment on the link between intellectual capital and firm performance taking the degree of technological intensity into account, the below models are generated. As demonstrated in Table no. 4 below, models (1) and (3) are developed to investigate the link between IC and selected measures of firm financial performance, models (2) and (4) are utilized to further evaluate the impact of individual IC components on the performance measures. It is important to note that all of these models are estimated for each of the four groups that segregate firms according to technological intensity, making up a total of 16 models. 
Table no. 4 - Models utilized and their representations

\begin{tabular}{lll}
\hline \multicolumn{1}{c}{ Model } & Functional Representations & Equation No \\
\hline $\mathrm{ROA}=f(\mathrm{VAIC}, \mathrm{SIZE}, \mathrm{LEV})$ & $R O A_{i t}=\beta_{0}+\beta_{1} V A I C_{i t}+\beta_{2} \mathrm{SIZE}_{i t}+\beta_{3} L E V_{i t}+\epsilon_{i t}$ & $(1)$ \\
\hline $\mathrm{ROA}=f(\mathrm{CEE}, \mathrm{HCE}, \mathrm{SCE}, \mathrm{SIZE}, \mathrm{LEV})$ & $R O A_{i t}=\beta_{0}+\beta_{1} C E E_{i t}+\beta_{2} H C E_{i t}+\beta_{3} S C E_{i t}+\beta_{4} \mathrm{SIZE}_{i t}+\beta_{5} L E V_{i t}+\epsilon_{i t}$ \\
\hline $\mathrm{ROE}=f(\mathrm{VAIC}, \mathrm{SIZE}, \mathrm{LEV})$ & $R O E_{i t}=\beta_{0}+\beta_{1} V A I C_{i t}+\beta_{2} \mathrm{SIZE}_{i t}+\beta_{3} L E V_{i t}+\epsilon_{i t}$ \\
\hline $\mathrm{ROE}=f(\mathrm{CEE}, \mathrm{HCE}, \mathrm{SCE}, \mathrm{SIZE}, \mathrm{LEV})$ & $R O E_{i t}=\beta_{0}+\beta_{1} C E E_{i t}+\beta_{2} \mathrm{HCE}_{i t}+\beta_{3} S C E_{i t}+\beta_{4} \mathrm{SIZE}_{i t}+\beta_{5} L E V_{i t}+\epsilon_{i t}$ \\
\hline
\end{tabular}

In order to identify the estimator to be used for each of the 16 models, Likelihood-ratio (LR) test is conducted to find out the presence of either unit and/or time affects for all models. The results show that only the model in Group 2, which investigates the link between ROE and intellectual capital components, has neither unit or time effects making the model a classical one. Furthermore, Hausman test is performed to decide whether the remaining models demonstrate fixed or random effects, which are provided in the tables displaying the results for the models in detail. All models are tested to identify the potential presence of heteroskedasticity, autocorrelation, and cross-sectional independence to find out whether the basic assumptions of panel data models are satisfied. Accordingly, due to the presence of heteroskedasticity, autocorrelation, and cross-sectional independence; all models except the classical one, are regressed with Driscoll-Kraay standard errors (Tatoğlu, 2020, pp. 338-339). Lastly, since the classical model displays only heteroskedasticity, it is regressed with Pooled OLS corrected for robust standard errors (Tatoğlu, 2020, p. 305).

\section{FINDINGS AND DISCUSSIONS}

The descriptive statistics of the variables utilized in the models for each group are provided in Table no. 5 below. To eliminate the outliers with respect to the major variables of interest, scatter diagram analyses have been performed. The final number of firm-year observations free from extreme values can be found in the tables displaying the results of the models.

Table no. 5 - Summary statistics of the variables utilized

\begin{tabular}{|c|c|c|c|c|c|}
\hline \multicolumn{6}{|c|}{ Group 1: High technological intensity } \\
\hline Variables & Observation & Mean & Min & Max & Std. Dev. \\
\hline \multicolumn{6}{|c|}{ Dependent variables } \\
\hline ROA & 836 & 0.043 & -0.284 & 0.380 & 0.075 \\
\hline ROE & 836 & 0.072 & -0.889 & 0.468 & 0.124 \\
\hline \multicolumn{6}{|c|}{ Explanatory variables } \\
\hline VAIC & 836 & 3.366 & -20.041 & 203.934 & 8.978 \\
\hline CEE & 836 & 0.318 & -0.209 & 86.053 & 2.972 \\
\hline $\mathrm{HCE}$ & 836 & 2.494 & -2.333 & 202.750 & 7.591 \\
\hline SCE & 836 & 0.554 & -20.091 & 96.118 & 3.792 \\
\hline \multicolumn{6}{|c|}{ Control variables } \\
\hline SIZE & 836 & 16.665 & 11.597 & 24.906 & 2.689 \\
\hline LEV & 836 & 0.409 & 0.011 & 0.920 & 0.191 \\
\hline
\end{tabular}




\begin{tabular}{|c|c|c|c|c|c|}
\hline \multicolumn{6}{|c|}{ Group 2: Medium-high technological intensity } \\
\hline Variables & Observation & Mean & Min & Max & Std. Dev. \\
\hline \multicolumn{6}{|c|}{ Dependent variables } \\
\hline ROA & 1,287 & 0.045 & -0.525 & 0.444 & 0.073 \\
\hline ROE & 1,287 & 0.082 & -4.141 & 7.301 & 0.284 \\
\hline \multicolumn{6}{|c|}{ Explanatory variables } \\
\hline VAIC & 1,287 & 12.149 & -68.150 & $12,031.970$ & 335.329 \\
\hline CEE & 1,287 & 0.194 & -0.189 & 1.383 & 0.139 \\
\hline $\mathrm{HCE}$ & 1,287 & 11.644 & -7.442 & $12,030.680$ & 335.295 \\
\hline SCE & 1,287 & 0.311 & -68.165 & 7.982 & 2.704 \\
\hline \multicolumn{6}{|c|}{ Control variables } \\
\hline SIZE & 1,287 & 16.563 & 10.383 & 26.573 & 2.844 \\
\hline LEV & 1,287 & 0.466 & 0.029 & 1.066 & 0.189 \\
\hline \multicolumn{6}{|c|}{ Group 3: Medium-low technological intensity } \\
\hline Variables & Observation & Mean & Min & Max & Std. Dev. \\
\hline \multicolumn{6}{|c|}{ Dependent variables } \\
\hline ROA & 1,606 & 0.046 & -0.603 & 1.065 & 0.075 \\
\hline ROE & 1,606 & 0.072 & -5.090 & 1.281 & 0.220 \\
\hline \multicolumn{6}{|c|}{ Explanatory variables } \\
\hline VAIC & 1,606 & 16.184 & -103.278 & $12,031.966$ & 322.699 \\
\hline CEE & 1,606 & 0.159 & -0.570 & 1.383 & 0.116 \\
\hline $\mathrm{HCE}$ & 1,606 & 15.471 & -104.275 & $12,030.678$ & 322.675 \\
\hline SCE & 1,606 & 0.554 & -7.397 & 25.865 & 0.911 \\
\hline \multicolumn{6}{|c|}{ Control variables } \\
\hline SIZE & 1,606 & 16.846 & 10.724 & 25.095 & 2.874 \\
\hline LEV & 1,606 & 0.435 & 0.020 & 2.285 & 0.199 \\
\hline \multicolumn{6}{|c|}{ Group 4: Low technological intensity } \\
\hline Variables & Observation & Mean & Min & Max & Std. Dev. \\
\hline \multicolumn{6}{|c|}{ Dependent variables } \\
\hline ROA & 1,815 & 0.047 & -1.194 & 0.641 & 0.090 \\
\hline ROE & 1,815 & 0.096 & -5.448 & 24.192 & 0.667 \\
\hline \multicolumn{6}{|c|}{ Explanatory variables } \\
\hline VAIC & 1,815 & 8.337 & $-1,530.592$ & $4,218.443$ & 116.933 \\
\hline CEE & 1,815 & 0.180 & -0.385 & 0.844 & 0.136 \\
\hline $\mathrm{HCE}$ & 1,815 & 7.593 & $-12,915$ & $4,217.192$ & 104.368 \\
\hline SCE & 1,815 & 0.563 & $-1,530.593$ & $1,640.061$ & 52.689 \\
\hline \multicolumn{6}{|c|}{ Control variables } \\
\hline SIZE & 1,815 & 16.959 & 10.447 & 25.559 & 3.299 \\
\hline LEV & 1,815 & 0.474 & -0.049 & 3.500 & 0.294 \\
\hline
\end{tabular}

Table no. 6 displays the results of the models (1) - (4) for Group 1 and Group 2, which includes firms with the highest and medium high technological intensity, investigating the effect of intellectual capital and its components on selected firm performance measures to test the above stated hypothesis in Section 3. The findings under group 1 for models (1) and (3) provide evidence as to the positive and significant impact of intellectual capital proxied by VAIC on both of the financial performance measures. With respect to the findings as to the components of VAIC, whereas CEE and HCE are documented to be positive contributors to both performance measures; SCE is not found to display any significant impact. Additionally, the influence of CEE on both ROA and ROE is documented to be more strongly pronounced as can be seen from the higher coefficients in comparison to those of HCE. An evaluation of the results for the control variables shows that firm size is found to positively contribute to 
the selected performance measures for all models. When the results for LEV is analyzed, it is seen that there is a negative and significant link between debt level of the firms and financial performance except for model (4). This variable's impact on performance is more significant for the models that utilize ROA.

Table no. 6 - Results of analysis for companies under Group 1 - Group 2

\begin{tabular}{|c|c|c|c|c|c|c|c|c|}
\hline \multirow{3}{*}{$\begin{array}{l}\text { Sector } \\
\text { Dependent Variable } \\
\text { Models }\end{array}$} & \multicolumn{4}{|c|}{ Group 1 - High Technology } & \multicolumn{4}{|c|}{ Group 2 - Medium High Technology } \\
\hline & \multicolumn{2}{|c|}{ ROA } & \multicolumn{2}{|c|}{ ROE } & \multicolumn{2}{|c|}{ ROA } & \multicolumn{2}{|c|}{ ROE } \\
\hline & $\begin{array}{l}\text { Model(1) } \\
\text { FE }\end{array}$ & $\begin{array}{c}\text { Model(2) } \\
\text { FE }\end{array}$ & $\begin{array}{l}\text { Model(3) } \\
\text { FE }\end{array}$ & $\begin{array}{l}\text { Model(4) } \\
\text { FE }\end{array}$ & $\begin{array}{c}\text { Model(1) } \\
\text { RE }\end{array}$ & $\begin{array}{c}\text { Model(2) } \\
\text { FE }\end{array}$ & $\begin{array}{c}\text { Model(3) } \\
\text { RE }\end{array}$ & $\begin{array}{l}\text { Model(4) } \\
\text { CL }\end{array}$ \\
\hline VAIC & $\begin{array}{l}.012 * * * \\
(.003)\end{array}$ & & $\begin{array}{l}.018 * * * \\
(.004)\end{array}$ & & $\begin{array}{c}.014 * * * \\
(.002)\end{array}$ & & $\begin{array}{c}.028 * * * \\
(.004)\end{array}$ & \\
\hline CEE & & $\begin{array}{l}.439 * * * \\
(.023)\end{array}$ & & $\begin{array}{c}.709^{* * * *} \\
(.056)\end{array}$ & & $\begin{array}{c}.397 * * * * \\
(.274)\end{array}$ & & $\begin{array}{c}.444 * * * * \\
(.086)\end{array}$ \\
\hline HCE & & $\begin{array}{l}.018 * * * \\
(.003)\end{array}$ & & $\begin{array}{l}.027 * * * * \\
(.003)\end{array}$ & & $\begin{array}{l}.011 * * * \\
(.002)\end{array}$ & & $\begin{array}{l}.026 * * \\
(.013)\end{array}$ \\
\hline SCE & & $\begin{array}{c}.006 \\
(.008)\end{array}$ & & $\begin{array}{c}.005 \\
(.009)\end{array}$ & & $\begin{array}{l}.012 * \\
(.005)\end{array}$ & & $\begin{array}{c}.057 \\
(.066)\end{array}$ \\
\hline SIZE & $\begin{array}{c}.019 * * * \\
(.004)\end{array}$ & $\begin{array}{c}.012 * * * \\
(.003)\end{array}$ & $\begin{array}{c}.039 * * * \\
(.012)\end{array}$ & $\begin{array}{c}.0292 * * * \\
(.009)\end{array}$ & $\begin{array}{l}.0003 \\
(.002)\end{array}$ & $\begin{array}{c}.011 * * * \\
(.003)\end{array}$ & $\begin{array}{r}-.0002 \\
(.004)\end{array}$ & $\begin{array}{c}.004 \\
(.003)\end{array}$ \\
\hline LEV & $\begin{array}{c}-.149 * * * \\
(.046)\end{array}$ & $\begin{array}{c}-.080 * * * \\
(.018)\end{array}$ & $\begin{array}{l}-.228 * \\
(.113)\end{array}$ & $\begin{array}{l}-.113 \\
(.070)\end{array}$ & $\begin{array}{c}-.112 * * * \\
(.014)\end{array}$ & $\begin{array}{c}-.100 * * * \\
(.024)\end{array}$ & $\begin{array}{c}-.0858 * * * \\
(.256)\end{array}$ & $\begin{array}{c}.016 \\
(.107)\end{array}$ \\
\hline constant & $\begin{array}{c}-.245 * * * \\
(.061)\end{array}$ & $\begin{array}{c}-.267 * * * \\
(.056)\end{array}$ & $\begin{array}{c}-.540 * * * \\
(.172)\end{array}$ & $\begin{array}{c}-.581 * * * * \\
(.148)\end{array}$ & $\begin{array}{l}.053^{*} \\
(.025)\end{array}$ & $\begin{array}{c}-.209 * * * \\
(.044)\end{array}$ & $\begin{array}{l}.043 \\
(.055)\end{array}$ & $\begin{array}{l}-.157 * * \\
(.065)\end{array}$ \\
\hline $\begin{array}{l}\text { Number of } \\
\text { observations }\end{array}$ & 828 & 824 & 828 & 824 & 1282 & 1272 & 1280 & 1275 \\
\hline Number of groups & 76 & 76 & 76 & 76 & 117 & 117 & 117 & \\
\hline F & 10.28 & 1284.04 & 8.56 & 221.68 & & 394.74 & & 30.84 \\
\hline Prob $>$ F & 0.002 & 0.000 & 0.004 & 0.000 & & 0.0000 & & 0.0000 \\
\hline Wald chi2 & & & & & 106.87 & & 82.78 & \\
\hline $\begin{array}{l}\text { Prob > Chi2 } \\
\text { R-squared }\end{array}$ & & & & & 0.0000 & & 0.0000 & 0.092 \\
\hline $\begin{array}{l}\text { Within R-squared } \\
\text { Overall R-squared }\end{array}$ & 0.217 & 0.613 & 0.155 & 0.480 & 0.270 & 0.4299 & 0.162 & \\
\hline $\begin{array}{l}\mathrm{FE}=\text { Fixed effect } \\
\mathrm{RE}=\text { Random Effect } \\
\mathrm{CL}=\text { Classical Model }\end{array}$ & $\begin{array}{l}\text { All model } \\
\text { Kraay stan } \\
* p<0.10\end{array}$ & $\begin{array}{l}\text { are regress } \\
\text { dard errors. } \\
* * p<0.05 ;\end{array}$ & $* * * p<0.01$ & & $\begin{array}{l}\text { Models (1) } \\
\text { Driscoll-K } \\
\text { is regressec }\end{array}$ & $\begin{array}{l}\text {, (2), and (3 } \\
\text { raay standar } \\
\text { d with Poole }\end{array}$ & $\begin{array}{l}\text { are regre } \\
\text { d errors an } \\
\text { d OLS est }\end{array}$ & $\begin{array}{l}\text { d with } \\
\text { Model (4) } \\
\text { ator }\end{array}$ \\
\hline
\end{tabular}

The findings for group 2 display the positive and significant influence of VAIC on the financial performance of the firms proxied by ROA and ROE. An evaluation of the findings with respect to components of intellectual capital provide evidence that CEE and HCE are positive and significant contributors to the selected performance measures. However; while SCE is found to positively influence ROA, it is not found to exert any impact on ROE. Further analysis shows that the results for the firm size are not consistent across the models in that it is only positive and significant for model (2). The leverage of the firm reveals comparatively more consistent findings as its coefficient is significantly negative for models (1), (2), and (3).

Table no. 7 displays the results of the models (1) - (4) for Group 3 and Group 4, which includes firms with the medium low and low technological intensity. A quick glance at Table no. 7 reveals that all of the major variables of interest that are intellectual capital and its components, provide consistent results for all models in Group 3, which is composed of firms 
with medium-low level of technology. Accordingly, VAIC is found to be a positive and significant contributor to both financial performance indicators. In terms of the components; whereas the coefficients of CEE and HCE are positive and significant, that of SCE turns out to be insignificant as can be seen in models (2) and (4). Additionally, while SIZE is found to exert a positive impact on performance in models that utilize intellectual capital components, LEV is documented to be negatively related with performance for the models that utilize ROA as the performance measure.

Table no. 7 - Results of analysis for companies under Group 3 - Group 4

\begin{tabular}{|c|c|c|c|c|c|c|c|c|}
\hline \multirow{2}{*}{$\begin{array}{l}\text { Sector } \\
\text { Dependent Variable }\end{array}$} & \multicolumn{4}{|c|}{ Group 3 - Medium Low Technology } & \multicolumn{4}{|c|}{ Group 4-Low Technology } \\
\hline & \multicolumn{2}{|c|}{ ROA } & \multicolumn{2}{|c|}{ ROE } & \multicolumn{2}{|c|}{ ROA } & \multicolumn{2}{|c|}{ ROE } \\
\hline Models & Model(1) & Model(2) & Model(3) & Model(4) & Model(1) & Model(2) & Model(3) & Model(4) \\
\hline Methods & $\mathbf{R E}$ & FE & RE & RE & FE & FE & RE & FE \\
\hline VAIC & $\begin{array}{l}.004 * * * \\
(.0008)\end{array}$ & & $\begin{array}{l}.010 * * * \\
(.002)\end{array}$ & & $\begin{array}{l}.002 * * * \\
(.0007)\end{array}$ & & $\begin{array}{l}.008 * * * \\
(.002)\end{array}$ & \\
\hline CEE & & $\begin{array}{c}.446 * * * \\
(.023)\end{array}$ & & $\begin{array}{l}.677 * * * \\
(.039)\end{array}$ & & $\begin{array}{l}.438 * * * \\
(.021)\end{array}$ & & $\begin{array}{l}.942 * * * \\
(.057)\end{array}$ \\
\hline HCE & & $\begin{array}{l}.004 * * * \\
(.0004)\end{array}$ & & $\begin{array}{l}.005 * * * \\
(.001)\end{array}$ & & $\begin{array}{l}.004 * * * \\
(.0005)\end{array}$ & & $\begin{array}{l}.009 * * * \\
(.002)\end{array}$ \\
\hline SCE & & $\begin{array}{c}.004 \\
(.004)\end{array}$ & & $\begin{array}{c}.007 \\
(.008)\end{array}$ & & $\begin{array}{l}-.0009 \\
(.003)\end{array}$ & & $\begin{array}{l}-.018 \\
(.020)\end{array}$ \\
\hline SIZE & $\begin{array}{r}-.0008 \\
(.002)\end{array}$ & $\begin{array}{l}.004 * * \\
(.002)\end{array}$ & $\begin{array}{l}-.0008 \\
(.002)\end{array}$ & $\begin{array}{l}.003 * \\
(.001)\end{array}$ & $\begin{array}{l}-.001 \\
(.003)\end{array}$ & $\begin{array}{c}.008 * * * \\
(.001)\end{array}$ & $\begin{array}{c}.001 \\
(.006)\end{array}$ & $\begin{array}{l}-.008 \\
(.018)\end{array}$ \\
\hline LEV & $\begin{array}{c}-.084 * * * \\
(.011)\end{array}$ & $\begin{array}{c}-.070 * * * \\
(.015)\end{array}$ & $\begin{array}{l}-.090 \\
(.054)\end{array}$ & $\begin{array}{l}-.045 \\
(.044\end{array}$ & $\begin{array}{c}-.096 * * * \\
(.017)\end{array}$ & $\begin{array}{c}-.082 * * * \\
(.015)\end{array}$ & $\begin{array}{l}-.036 \\
(.054)\end{array}$ & $\begin{array}{l}.044 \\
(.103)\end{array}$ \\
\hline constant & $\begin{array}{c}.080 * * * \\
(.179) \\
\end{array}$ & $\begin{array}{c}-.078 * * \\
(.035)\end{array}$ & $\begin{array}{l}.092 * * \\
(.040) \\
\end{array}$ & $\begin{array}{c}-.075 * * \\
.028\end{array}$ & $\begin{array}{l}.101 * \\
(.054) \\
\end{array}$ & $\begin{array}{c}-.133 * * * \\
(.030) \\
\end{array}$ & $\begin{array}{c}.047 \\
(.105) \\
\end{array}$ & $\begin{array}{c}.013 \\
(.322) \\
\end{array}$ \\
\hline Number of observations & 1595 & 1588 & 1592 & 1583 & 1792 & 1779 & 1791 & 1787 \\
\hline Number of groups & 146 & 146 & 146 & 146 & 165 & 165 & 165 & 165 \\
\hline $\mathbf{F}$ & & 296.35 & & & 53.42 & 472.76 & & 79.89 \\
\hline Prob $>$ F & & 0.0000 & & & 0.0000 & 0.0000 & & 0.0000 \\
\hline Wald chi2 & 98.43 & & 74.4 & 414.56 & & & 69.03 & \\
\hline Prob > Chi2 & 0.0000 & & 0.0000 & 0.0000 & & & 0.0000 & \\
\hline Within R-squared & 0.423 & & & 0.059 & 0.307 & & 0.035 & \\
\hline Overall R-squared & 0.159 & & 0.076 & 0.247 & & & 0.0088 & \\
\hline $\begin{array}{l}\mathrm{FE}=\text { Fixed effect } \\
\mathrm{RE}=\text { Random Effect } \\
\mathrm{CL}=\text { Classical Model }\end{array}$ & $\begin{array}{l}\text { All mode } \\
* p<0.10\end{array}$ & $\begin{array}{l}\mathrm{s} \text { are regre } \\
* * p<00\end{array}$ & $\begin{array}{l}\text { sed with Di } \\
; * * * p<0.0\end{array}$ & riscoll-Kr & y standard & errors. & & \\
\hline
\end{tabular}

The findings for Group 4 made up of firms with low technology are also consistent with respect to VAIC and its components in all models. As can be seen, intellectual capital is a significant contributor to both ROA and ROE. Even though SCE is not significant for models that utilize VAIC components, CEE and HCE are positively related with selected proxies of performance. With respect to control variables, while SIZE is a contributor to performance in only model (2), LEV is negatively and significantly related with firm performance only for models (1) and (2).

To be more precise, a groupwise comparison can be made with respect to all the variables that are embedded into 16 models. It is seen that intellectual capital is a significant contributor to the financial performance of the firms in all groups. However, there is a general trend with respect to the magnitude of the coefficient belonging to the measure of intellectual capital; 
namely VAIC, in that it is higher for groups that are more technology intensive for both performance measures. No such trend has been detected for the variables standing for intellectual capital components. However, the significant contributors to financial performance in terms of VAIC components are analyzed to be CEE and HCE with CEE having the highest impact in all models for both performance measures. Additionally, it can be emphasized that the magnitude of the coefficients of the significant variables that are utilized to proxy for intellectual capital and its components is higher for the models that utilize ROE as the performance measure. Lastly, SCE is not documented to be significant for any of the models except model (2) of group with medium-high level of technology though with a significance level of $10 \%$. With respect to the control variables, size is found to be a contributor to both measures of performance for all the models in the group of firms with the highest technology. For the other groups no such comment can be made but the coefficient of this variable is reported to be positive for all the models where it is found to be significant. Firm leverage is found to be negatively and significantly related with performance in all groups where ROA is the selected proxy. In all the other models where LEV is found to be significant, the sign of the coefficient is negative.

The findings of this study are consistent with other studies that also utilize a crosscountry dataset. The positive influence of intellectual capital on financial performance has been detected in some works; namely, those of Nadeem et al. (2019), Sardo and Serrasqueiro (2018), and Dzenopoljac et al. (2017). This positive association has also been revealed in studies that utilize a single country dataset some of which can be listed as Weqar et al. (2020), Ginesti et al. (2018), Nadeem et al. (2016), Sumedrea (2013), and Zeghal and Maaloul (2010). The study of Sardo and Serrasqueiro (2018), which follows a similar approach as the one in this study segregating firms according to $R \& D$ intensity, also documents the positive influence of IC on financial performance for all groups of firms; namely, high-, medium- and low-tech European firms.

Referring to prior empirical work with respect to components of IC shows that findings differ across components depending on the dataset and period selected. The positive influence of CEE on financial performance is seen in the studies of Smriti and Das (2018), Sardo and Serrasqueiro (2018), Dzenopoljac et al. (2017), and Nadeem et al. (2016). The contribution of HCE to financial performance is documented by Xu and Wang (2018), Rahman (2012), Maditinos et al. (2011), and Goh (2005).

\section{CONCLUSION AND IMPLICATION}

The potential impact of IC and its components on firm financial performance is investigated in this study for 17 countries selected from Morgan Stanley Capital International (MSCI) Emerging Market Index for the period between 2009 and 2019. The dataset is categorized into four groups, namely; high, medium-high, medium-low, and low technology, based on technological intensity to reveal whether firms with varying degrees of $R \& D$ investment act differently in the above stated relationship. An evaluation of the findings provides evidence that IC significantly contributes to financial performance measured by ROA and ROE for all groups of firms. Furthermore, a general trend has been detected in that firms that are more technological intensive display a stronger link between IC and financial performance. In terms of the components, while structural capital denoted by SCE is not found to have any significant effect, physical capital and human capital, denoted by CEE and HCE 
respectively, are found to be positively influencing financial performance with CEE having the highest impact. Finally, the significant contribution of IC and its components to selected measures of performance is stronger for ROE in comparison to ROA.

The findings contribute to the array of literature in IC in that IC and its components are found to be significant drivers of financial performance in the emerging market context. Therefore, for practical purposes managers should focus on improving IC. On the other hand, managers should particularly invest in human and physical capital irrespective of technological intensity as these two components are found to boost finance performance for all groups.

The current study rests upon the fact that it utilizes a dataset of 17 emerging countries; thus, the country-wise differences are not analyzed limiting the evaluation of findings as to a specific country. Due to country specific factors such as culture, laws, regulations, policies, accounting practices, and industrial concentration; results may differ when analyses are conducted for individual countries. Therefore, future research can focus on a particular country and compare the results with multi-country studies. Furthermore, the scope of the dataset is limited to MSCI emerging countries. Additional studies can be performed in developed markets so that the outcomes can be compared with those of the emerging ones. Lastly, depending on the assumption that the influence of IC on performance can take time to actualize, additional analyses can be performed taking lagged performance into account in the models.

\section{Acknowledgements}

This study is part of a project, which is supported by Marmara University, Scientific Research Projects Committee, Project Number SOS-A-120619-0243.

\section{ORCID}

Mehtap Öner (iD https://orcid.org/0000-0001-7527-5875

Asl1 Aybars iD https://orcid.org/0000-0002-7899-2367

Murat Çinko iD https://orcid.org/0000-0001-8560-7482

Emin Avc1 iD https://orcid.org/0000-0003-3172-897X

\section{References}

Akpına, O., \& Akpınar, A. T. (2016). Entellektüel sermaye bileşenlerinin işletme değerine ve performansına etkisi: Türkiye'deki imalat işletmeleri örneği. Kastamonu Üniversitesi İktisadi ve İdari Bilimler Fakültesi Dergisi, 12, 142-153.

Avc1, E., \& Nassar, S. (2017). Intellectual capital and its impact on firm performance of the Turkish financial sector before and after financial crisis. PressAcademia Procedia, 3, 916-924. http://dx.doi.org/10.17261/Pressacademia.2017.674

Baltagi, B. H. (2001). Econometric analysis of panel data (2nd ed.). United Kingdom: Wiley\&Sons, Ltd.

Barney, J. (1991). Firm resources and sustained competitive advantage. Journal of Management, 17(1), 99-120. http://dx.doi.org/10.1177/014920639101700108

Bontis, N. (1998). Intellectual capital: An exploratory study that develops measures and models. Management Decision, 36(2), 63-76. http://dx.doi.org/10.1108/00251749810204142

Bontis, N. (2001). Assessing knowledge assets: A review of the models used to measure intellectual capital. International Journal of Management Reviews, 3(1), 41-60. http://dx.doi.org/10.1111/1468-2370.00053 
Bontis, N., Janosevic, S., \& Dzenopoljac, V. (2015). Intellectual capital in Serbia's hotel industry. International Journal of Contemporary Hospitality Management, 27(6), 1365-1384. http://dx.doi.org/10.1108/IJCHM-12-2013-0541

Bontis, N., Keow, W. C. C., \& Richardson, S. (2000). Intellectual capital and business performance in Malaysian industries. Journal of Intellectual Capital, 1(1), 85-100. http://dx.doi.org/10.1108/14691930010324188

Buenechea-Elberdin, M. (2017). Structured literature review about intellectual capital and innovation. Journal of Intellectual Capital, 18(2), 262-285. http://dx.doi.org/10.1108/JIC-07-2016-0069

Buenechea-Elberdin, M., Saenz, J., \& Kianto, A. (2018). Knowledge management strategies, intellectual capital, and innovation performance: A comparison between high- and low-tech firms. Journal of Knowledge Management, 22(8), 1757-1781. http://dx.doi.org/10.1108/JKM-04-2017-0150

Celenza, D., \& Rossi, F. (2014). Intellectual capital and performance of listed companies: Empirical evidence from Italy. Measuring Business Excellence, 18(1), 22-35. http://dx.doi.org/10.1108/MBE-10-2013-0054

Chan, K. H. (2009). Impact of intellectual capital on organisational performance: An empirical study of companies in the Hang Seng Index (Part 2). The Learning Organization, 16(1), 22-39. http://dx.doi.org/10.1108/09696470910927650

Clarke, M., Seng, D., \& Whiting, R. H. (2011). Intellectual capital and firm performance in Australia. Journal of Intellectual Capital, 12(4), 505-530. http://dx.doi.org/10.1108/14691931111181706

Crane, L., \& Bontis, N. (2014). Trouble with tacit: Developing a new perspective and approach. Journal of Knowledge Management, 18(6), 1127-1140. http://dx.doi.org/10.1108/JKM-02-2014-0061

Dzenopoljac, V., Yaacoub, C., Elkanj, N., \& Bontis, N. (2017). Impact of intellectual capital on corporate performance: Evidence from the Arab region. Journal of Intellectual Capital, 18(4), 884-903. http://dx.doi.org/10.1108/JIC-01-2017-0014

Edvinsson, L. (1997). Developing intellectual capital at Skandia. Long Range Planning, 30(3), 366-373. http://dx.doi.org/10.1016/S0024-6301(97)90248-X

Edvinsson, L., \& Malone, M. (1997). Intellectual capital: Realizing your company's true value by finding its hidden roots. New York: Harper Collins.

Firer, S., \& Williams, S. M. (2003). Intellectual capital and traditional measures of corporate performance. Journal of Intellectual Capital, 4(3), 348-360. http://dx.doi.org/10.1108/14691930310487806

Ginesti, G., Caldarelli, A., \& Zampella, A. (2018). Exploring the impact of intellectual capital on company reputation and performance. Journal of Intellectual Capital, 19(5), 915-934. http://dx.doi.org/10.1108/JIC-01-2018-0012

Goh, P. C. (2005). Intellectual capital performance of commercial banks in Malaysia. Journal of Intellectual Capital, 6(3), 385-396. http://dx.doi.org/10.1108/14691930510611120

Gülcemal, T., \& Çıtak, L. (2017). Entelektüel katma değer katsayısı yöntemi ile ölçülen entelektüel sermayenin firma performansı üzerindeki etkisi. Journal of Economics and Administrative Sciences, 8(1), 35-55.

Hall, R. (1992). The strategic analysis of intangible resources. Strategic Management Journal, 13(2), 135-144. http://dx.doi.org/10.1002/smj.4250130205

Hamdan, A. (2018). Intellectual capital and firm performance: Differentiating between accountingbased and market-based performance. International Journal of Islamic and Middle Eastern Finance and Management, 11(1), 139-151. http://dx.doi.org/10.1108/IMEFM-02-2017-0053

Iazzolino, G., \& Laise, D. (2013). Value added intellectual coefficient (VAIC): A methodological and critical review. Journal of Intellectual Capital, 14(4), 547-563. http://dx.doi.org/10.1108/JIC-122012-0107

Johnson, W. H. A. (1999). Integrative taxonomy of intellectual capital: Measuring the stock and flow of intellectual capital components in the firm. International Journal of Technology Management, 18(5/6/7/8), 562-575. http://dx.doi.org/10.1504/IJTM.1999.002788 
Jordao, R. V. D., \& Almeida, V. R. (2017). Performance measurement, intellectual capital and financial sustainability. Journal of Intellectual Capital, 18(3), 643-666. http://dx.doi.org/10.1108/JIC-112016-0115

Kayacan, M., \& Özkan, N. (2015). Entelektuel sermaye ve katılım bankalarının finansal performansına etkisi. Paper presented at the 19th Finance Symposium, Corum, Turkey.

Maditinos, D., Chatzoudes, D., Tsairidis, C., \& Theriou, G. (2011). The impact of intellectual capital on firms' market value and financial performance. Journal of Intellectual Capital, 12(1), 132-151. http://dx.doi.org/10.1108/14691931111097944

Mavridis, D. G. (2004). The intellectual capital performance of the Japanese banking sector. Journal of Intellectual Capital, 5(1), 92-115. http://dx.doi.org/10.1108/14691930410512941

Nadeem, M., Dumay, J., \& Massaro, M. (2019). If you can measure it, you can manage it: A case of Intellectual Capital. Australian Accounting Review, 29(2), 395-407. http://dx.doi.org/10.1111/auar.12227

Nadeem, M., Gan, C., \& Nyugen, C. (2016). Intellectual capital and firm performance: Static or dynamic estimation: Evidence from the UK Paper presented at the 8th European Conference on Intellectual Capital, Italy.

Nadeem, M., Gan, C., \& Nyugen, C. (2017). Does intellectual capital efficiency improve firm performance in BRICS economies? A dynamic panel estimation. Measuring Business Excellence, 2l(1), 65-85. http://dx.doi.org/10.1108/MBE-12-2015-0055

Nadeem, M., Gan, C., \& Nyugen, C. (2018). The importance of intellectual capital for firm performance: Evidence from Australia. Australian Accounting Review, 28(3), 334-344. http://dx.doi.org/10.1111/auar.12184

Nimtrakoon, S. (2015). The relationship between intellectual capital, firms' market value and financial performance: Empirical evidence from the ASEAN. Journal of Intellectual Capital, 16(3), 587618. http://dx.doi.org/10.1108/JIC-09-2014-0104

OECD. (1999). Measuring and reporting intellectual capital from a diverse Canadian industry perspective: Experience, issues and prospects economy Retrieved from https://www.oecd.org/industry/ind/1947855.pdf

Ousama, A. A., Hammami, H., \& Abdulkarim, M. (2020). The association between intellectual capital and financial performance in the Islamic banking industry: An analysis of the GCC banks. International Journal of Islamic and Middle Eastern Finance and Management, 13(1), 75-93. http://dx.doi.org/10.1108/IMEFM-05-2016-0073

Özkan, N., Cakan, S., \& Kayacan, M. (2017). Intellectual capital and financial performance: A study of the Turkish banking sector. Borsa Istanbul Review, 17(3), 190-198. http://dx.doi.org/10.1016/j.bir.2016.03.001

Palazzi, F., Sgro, F., Ciambotti, M., \& Bontis, N. (2020). Technological intensity as a moderating variable for the intellectual capital-performance relationship. Knowledge and Process Management, 27(1), 3-14. http://dx.doi.org/10.1002/kpm.1617

Petty, R., \& Guthrie, J. (2000). Intellectual capital literature review: Measurement, reporting and management. Journal of Intellectual Capital, $1(2), \quad 155-176$. http://dx.doi.org/10.1108/14691930010348731

Phusavat, K., Comepa, N., Sitko-Lutek, A., \& Ooi, K. B. (2011). Interrelationships between intellectual capital and performance: Empirical examination. Industrial Management \& Data Systems, 111(6), 810-829. http://dx.doi.org/10.1108/02635571111144928

Pulic, A. (1998). Measuring the performance of intellectual potential in a knowledge economy Paper presented at the 2nd McMaster World Congress.

Pulic, A. (2004). Intellectual capital - Does it create or destroy value? Measuring Business Excellence, 8(1), 62-68. http://dx.doi.org/10.1108/13683040410524757

Rahman, S. (2012). The role of intellectual capital in determining differences between stock market and financial performance. International Research Journal of Finance and Economics, 89, 46-77. 
Ramirez, Y., Dieguez-Soto, J., \& Manzaneque, M. (2021). How does intellectual capital efficiency affect firm performance? The moderating role of family management. International Journal of Productivity and Performance Management, 70(2), 297-324. http://dx.doi.org/10.1108/IJPPM03-2019-0119

Roos, G., \& Roos, J. (1997). Measuring your company's intellectual performance. Long Range Planning, 30(3), 413-426. http://dx.doi.org/10.1016/S0024-6301(97)90260-0

Roos, G., Roos, J., Edvinsson, L., \& Dragonetti, N. C. (1997). Intellectual capital - Navigating in the new business landscape: New York University Press.

Sakur, R. (2017). Entelektüel sermaye ile firma finansal performansi ilișkisi; BİST'te ișlem gören bankalar üzerine bir ekonometrik analiz. Paper presented at the International Conference on Eurasian Economies, Bishkek, Kyrgyzstan

Sardo, F., \& Serrasqueiro, Z. (2017). A European empirical study of the relationship between firms' intellectual capital, financial performance and market value. Journal of Intellectual Capital, 18(4), 771-788. http://dx.doi.org/10.1108/JIC-10-2016-0105

Sardo, F., \& Serrasqueiro, Z. (2018). Intellectual capital, growth opportunities, and financial performance in European firms: Dynamic panel data analysis. Journal of Intellectual Capital, 19(4), 747-767. http://dx.doi.org/10.1108/JIC-07-2017-0099

Sardo, F., Serrasqueiro, Z., \& Alves, H. (2018). On the relationship between intellectual capital and financial performance: A panel data analysis on SME hotels. International Journal of Hospitality Management, 75, 67-74. http://dx.doi.org/10.1016/j.ijhm.2018.03.001

Singla, H. K. (2020). Does VAIC affect the profitability and value of real estate and infrastructure firms in India? A panel data investigation. Journal of Intellectual Capital, 21(3), 309-331. http://dx.doi.org/10.1108/JIC-03-2019-0053

Smriti, N., \& Das, N. (2018). The impact of intellectual capital on firm performance: A study of Indian firms listed in COSPI. Journal of Intellectual Capital, 19(5), 935-964. http://dx.doi.org/10.1108/JIC-11-2017-0156

Stahle, P., Stahle, S., \& Aho, S. (2011). Value added intellectual coefficient (VAIC): A critical analysis Journal of Intellectual Capital, 12(4), 531-551. http://dx.doi.org/10.1108/14691931111181715

Stewart, T. (1997). Intellectual capital: The new wealth of organizations. New York: Bantam Doubleday Dell Publishing Group.

Sumedrea, S. (2013). Intellectual capital and firm performance: A dynamic relationship in crisis time. Procedia Economics and Finance, 6, 137-144. http://dx.doi.org/10.1016/S2212-5671(13)00125-

Sveiby, K. E. (1997). The new organizational wealth - Managing and measuring knowledge-based assets. San Francisco: Barrett-Kohler.

Tan, H. P., Plowman, D., \& Hancock, P. (2007). Intellectual capital and financial returns of companies. Journal of Intellectual Capital, 8(1), 76-95. http://dx.doi.org/10.1108/14691930710715079

Tatoğlu, F. Y. (2020). Panel veri ekonometrisi stata uygulamalı (5th ed. ed.). Istanbul: Beta Yayınları.

Ting, I. W. K., Ren, C., Chen, F. C., \& Kweh, Q. L. (2020). Interpreting the dynamic performance effect of intellectual capital through a value-added-based perspective. Journal of Intellectual Capital, 21(3), 381-401. http://dx.doi.org/10.1108/JIC-05-2019-0098

Tran, D. B., \& Vo, D. H. (2018). Should bankers be concerned with Intellectual capital? A study of the Thai banking sector. Journal of Intellectual Capital, 19(5), 897-914. http://dx.doi.org/10.1108/JIC-12-2017-0185

Weqar, F., Sofi, Z. A., \& Haque, S. M. I. (2020). Nexus between intellectual capital and business performance: Evidence from India. Asian Journal of Accounting Research, 6(2), 180-195. http://dx.doi.org/10.1108/AJAR-07-2020-0064

Wernerfelt, B. A. (1984). Resource-based view of the firm. Strategic Management Journal, 5(2), 171180. http://dx.doi.org/10.1002/smj.4250050207

Wooldridge, J. M. (2002). Econometric analysis of cross section and panel data. London: The MIT Press. 
Xu, J., \& Li, J. (2019). The impact of intellectual capital on SMEs' performance in China empirical evidence from non-high-tech vs. high-tech SMEs. Journal of Intellectual Capital, 20(4), 488-509. http://dx.doi.org/10.1108/JIC-04-2018-0074

Xu, J., \& Li, J. (2020). The interrelationship between intellectual capital and firm performance: Evidence from China's manufacturing sector. Journal of Intellectual Capital, ahead-of-print. http://dx.doi.org/10.1108/JIC-08-2019-0189

Xu, J., \& Wang, B. (2018). Intellectual capital, financial performance and companies' sustainable growth: Evidence from the Korean manufacturing industry. Sustainability, 10(2), 1-17. http://dx.doi.org/10.3390/su10124651

Yalaman, A., \& Coşkun, M. (2007). Intellectual capital performance of quoted banks on the Istanbul stock exchange market. Journal of Intellectual Capital, 8(2), 256-271. http://dx.doi.org/10.1108/14691930710742835

Yao, H., Haris, M., Tariq, G., Javaid, H. M., \& Khan, M. A. S. (2019). Intellectual capital, profitability, and productivity: Evidence from Pakistani financial institutions. Sustainability (Basel), 11(4), 130. http://dx.doi.org/10.3390/su11143842

Zeghal, D., \& Maaloul, A. (2010). Analysing value added as an indicator of intellectual capital and its consequences on company performance. Journal of Intellectual Capital, 11(1), 39-60. http://dx.doi.org/10.1108/14691931011013325

\section{Copyright}

This article is an open access article distributed under the terms and conditions of the Creative Commons Attribution-NonCommercial-NoDerivatives 4.0 International License. 